\title{
J-GLOBAL試行版＼cjkstart新機能と今後の方向性
}

\section{J-GLOBAL ( $\beta$ version) - New features and future directions}

植松 利晃 $^{1}$

\section{UEMATSU Toshiaki ${ }^{1}$}

1 独立行政法人科学技術振興機構イノベーション推進本部 文献情報部（テ102-8666 東京都千代田区四番町5-3）

Tel : 03-5214-8471

1 Department of Literature Information, Innovation Headquarters, Japan Science and Technology Agency

(5-3 Yonbancho Chiyoda-ku, Tokyo 102-8666)

\section{原稿受理 (2010-07-06)}

情報管理５3(6), 327-335, doi: 10.1241/johokanri.53.327 (http://dx.doi.org/10.1241/johokanri.53.327)

著者抄録

独立行政法人科学技術振興機構（JST）は，2010年6月1日にJ-GLOBAL（科学技術総合リンクセンター）試行版（ $\beta$ 版） 1.3 をリリースした。J-GLOBALは，「つながる ひろがる ひらめく」をキャッチフレーズに，これまでバラバラに 存在していた科学技術情報をつなぎ，発想を支援するユニークなサービスであり，JST 内外のさまざまな專門的なサー ビス等と連携し，質の高い科学技術情報をより効果的に流通させることで，わが国のイノベーション創出に貢献する ことを目指している。本稿ではこれまで実施したJ-GLOBALの機能改善の概要を中心に，J-GLOBALが目指す方向性に ついて紹介する。

キーワード

J-GLOBAL，データベース，イノベーション，連携、リンクセンター，辞書，文献，特許，研究者，研究機関

1.はじめに

独立行政法人科学技術振興機構 (JST) が提供して いるJ-GLOBAL（科学技術総合リンクセンター）試行 版（ $\beta$ 版）は「つながる ひろがる ひらめく」を キャッチフレーズに，これまでバラバラに存在して いた科学技術情報をつなぎ，発想を支援する新しい サービスとして，2009年3月30日に公開された1),2)。

本稿では，これまでのアクセス状況やアンケート 等の結果を踏まえて，最初のリリースから1年を経た 平成21年度に実施した機能改善の概要ならびに，今
後J-GLOBALが目指す方向性について紹介する。

\section{J-GLOBALの現状}

\section{1 アクセス数推移}

J-GLOBALは2009年3月のサービス公開以降，アク セスの集中によるレスポンスの低下を招いた時期も あったが，検索方式の变更等のチューニングを行い， 月間ページビュー数約400万〜 500万の間を推移して 現在に至っている（図1）。

図1中の累計訪問者数とはアクセスログからIPアド 


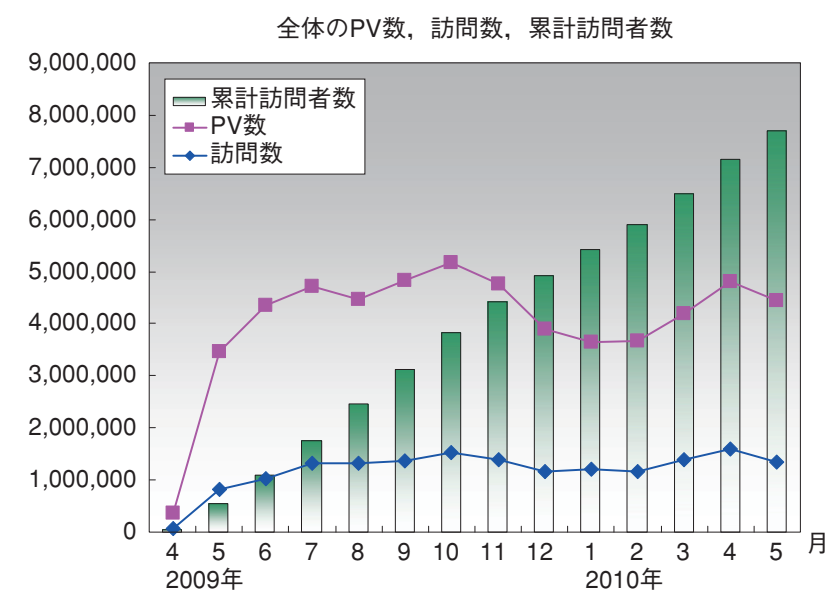

図1 J-GLOBALアクセス推移

レス，利用OS，利用ブラウザの組み合わせでの異な

りを1訪問者とみなし，それをリリース当初から初出 のものを累計したものである。2010年6月末時点の累 計で約 800 万となっており，複数の利用環境からの利 用を想定しても，多くの方々に利用いただいたこと になる。

\section{2 アンケート結果}

2010年2月〜3月にかけて，J-GLOBALの各ページに アンケート用のバナーを貼り，J-GLOBAL利用者に対 してアンケート調査 $\left.{ }^{3}\right)$ を実施し（有効回答数303）， J-GLOBALの使われ方の一端をうかがい知ることがで きた。

利用目的を尋ねたところ，「先行技術調査」や「共 同研究先の探索」を目的とする回答が多かった。そ れ以外の回答として「研究者個人の業績調査」や「志 望大学の検討のため」といった回答もあった（表1）。

J-GLOBALが役に立ったという回答は全体の9割に 達した。その理由としては，「無料で使える」や「思 いがけない情報が見つかる」、「信頼性が高い」といっ た回答が上位を占め，信頼性も重視している傾向が うかがえた（表2）。

J-GLOBALへの要望としては「リンク拡充」「網羅性」 「新鮮さ」「精度向上」などが上位を占め，発想を支 援するリンクセンターという位置づけを強化する方

表1 J-GLOBALアンケート 利用目的

【質問 3】J-GLOBAL の利用目的をお教えください(複数選択可)。 n:303

\begin{tabular}{|l|r|r|}
\hline \multicolumn{1}{|c|}{ 選択肢 } & カウント & 割合 $(\%)$ \\
\hline 新しい研究を立ち上げる時などの先行技術の調査のため & 105 & $34.7 \%$ \\
\hline 共同研究,受託研究等の相手を探すため & 82 & $27.1 \%$ \\
\hline 委員等の人選や,講演,査読,執筆の依頼先を探すため & 66 & $21.8 \%$ \\
\hline 同業他社の技術動向を把握するため & 51 & $16.8 \%$ \\
\hline 製品開発などの際の技術シーズ探索のため & 41 & $13.5 \%$ \\
\hline コンサルテイングなどの受託調査のため & 20 & $6.6 \%$ \\
\hline その他 & 80 & $26.4 \%$ \\
\hline
\end{tabular}

「その他」のコメント

・技術者,研究者の実績を知るため

・研究者個人の業績を調べる為

・人材登用の際の業績比較

・志望大学検討の際に, 自分の行いたい分野の研究者, 教授にどのような方がいるかを調べる。

表2 J-GLOBALアンケート 役に立つた理由

【質問 6】役に立った理由を下記からお選びください(複数選択可)。 n:303

\begin{tabular}{|l|r|r|}
\hline \multicolumn{1}{|c|}{ 選択肢 } & \multicolumn{1}{|c|}{ カウント } & 割合 $(\%)$ \\
\hline 無料で手軽に利用できる & 196 & $64.7 \%$ \\
\hline 思いがけない情報が見つかる & 147 & $48.5 \%$ \\
\hline 公的機関のサービスであり信頼性が高い & 114 & $37.6 \%$ \\
\hline 情報量が多い & 110 & $36.3 \%$ \\
\hline 時間が節約できる & 87 & $28.7 \%$ \\
\hline その他 & 14 & $4.6 \%$ \\
\hline
\end{tabular}


表3 J-GLOBALアンケート 要望

【質問 10】J-GLOBAL に対するご意見, ご要望等を下記からお選びください(複数選択可)。 n:303

\begin{tabular}{|l|r|r|}
\hline \multicolumn{1}{|c|}{ 選択肢 } & カウント & 割合 $(\%)$ \\
\hline 情報同士の関連や,他へのリンクがもっとあるとよい & 134 & $44.2 \%$ \\
\hline 情報にもっと網羅性があるとよい & 96 & $31.7 \%$ \\
\hline 情報にもっと新鮮さがあるとよい & 94 & $31.0 \%$ \\
\hline 関連情報一覽の精度をよくしてほしい & 73 & $24.1 \%$ \\
\hline 情報の画面表を分かりやすくしてほしい & 54 & $17.8 \%$ \\
\hline 検索速度の改善など検索をしやすくしてほしい & 48 & $15.8 \%$ \\
\hline ニュースやーケティング情報,企業情報と連携してほしい & 43 & $14.2 \%$ \\
\hline その他 & 48 & $15.8 \%$ \\
\hline
\end{tabular}

向が期待されていることがわかった（表3）。

\section{J-GLOBALの改善内容}

J-GLOBALのリリース直後からユーザーヒアリング を実施し，それに基づいたサービス拡充の方向性と して，(1)登載情報の充実，(2)連携の充実，(3)関連検 索の精度の向上，をINFOPRO2009にて報告した4)。 それを踏まえて，J-GLOBALは3回にわたり段階的に バージョンアップを実施した。ここでは，それぞれ のバージョンアップの内容を紹介する。

\section{1 \& $1.1 （ 2009$ 年12月15日公開）}

サービス開始当初は文献については発行日が2003 年以降，特許については公開日が2004年以降の登載 にとどまっていたが， $\beta 1.1$ より，特許・文献ともに 1993年以降の登載となった。

その他にも，検索空のデザイン刷新や，特許情報 に対して審査官が引用した特許の表示およびリンク に対応した。

\section{2 \& 1.2（2010年3月1日公開）}

及1.2ではWebAPIの公開を実施した。WebAPIとは， 利用者が自分で管理・運営しているWebサイトに JavaScriptをべースとしたスクリプトを組み込んで， J-GLOBALが保持しているリソースを検索し，取得さ れた検索結果を加工するなどして表示できるインタ フェースである5)。
WebAPIの利用には，キーの発行が必要であり，そ のため本バージョンからアカウントの登録も開始し た。このアカウント登録は $\beta 1.3$ でリリースされたMy J-GLOBALアカウントに引き継がれた。

その他にも，検索空を外部のサイト上に埋め込む ことができるスクリプトを公開した。現在，このイ ンタフェースを使った連携として，日経BP社が提供 する「日経BPビズボード」6) の有料ページにて論文・ 研究者検索として実装いただいている。

\section{$3.3 \beta 1.3$ (2010年6月1日公開）}

及 1.3ではこれまでのバージョンアップの中で最も 大規模な機能改善を実施した。大きく分けて，次の ようなカテゴリに分けられる。

・画面改善

-My J-GLOBAL機能追加

・データ拡充／リンク拡充

・関連検索の精度の向上

\subsection{1 画面改善（検索結果画面）}

画面デザインは広範囲にわたつて改善された。こ こでは検索結果画面デザインの改善点について紹介 する(図2)。

\section{a）スコアグラフの表示}

（図2中(1) J-GLOBALでは検索結果一覧の初期表示 は関連度スコアの高い順で表示される。このスコア をグラフ表示することが本機能であるが，ここでは スコア計算の仕組みを改めて紹介したい。J-GLOBAL 


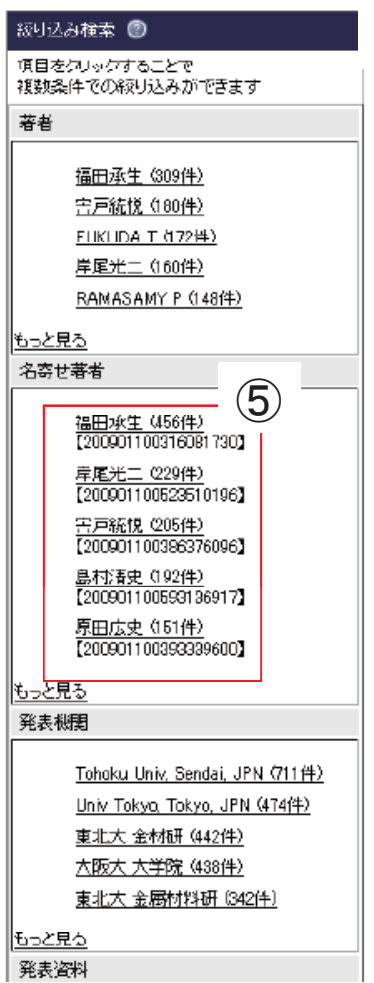

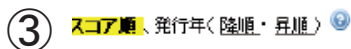

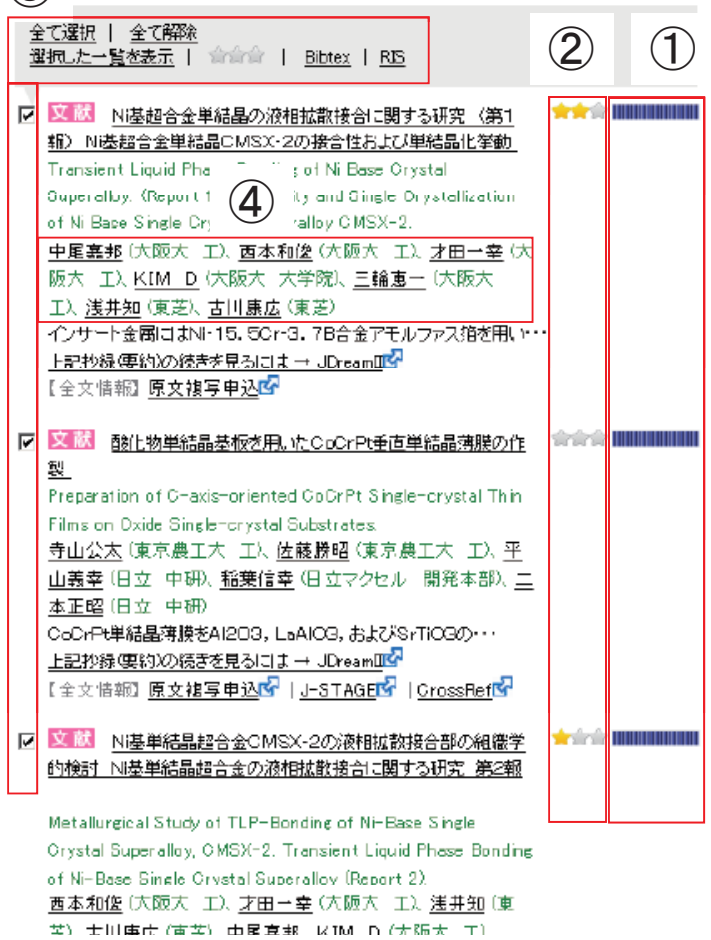

図2 検索結果画面の改善点
の検索では，入力された文字列を「研究者名」「機関 名」「用語」「その他」のいずれかに判定し，それぞ れに対応したスコアマップを保持している。例えば， 入力キーワードが「研究者名」と判定されると，研 究者情報では「研究者名」に，文献情報では「著者名」 に，特許情報では「発明者」に該当の文字列がある 場合にスコアが高くなる。「機関名」の場合は所属機 関や出願人のエリアのスコアが高くなる。このよう に各スコアマップを基に算出された各項目ごとの得 点が集計され，最終的なスコアに対数処理などをし て正規化を行った上でグラフを表示する。

なお，入力したキーワードがどのように判定され たかは，検索結果画面右にある別名展開エリアの見 出しで示される。

b）ブックマーク登録

(図2中(2)）My J-GLOBALの機能のひとつである。 検索結果画面で，各基本情報ごとに印が表示され る。ログイン中に，興味のある基本情報を後でまた 閲覧したい場合に，々印をクリックするとブックマー
ク登録される。印印は後で分類しやすいように3段階 の指定をすることができ，段階の変更も自由に行え る。登録したブックマークはMy J-GLOBALページよ り閲覧できる。ログイン前に々印をクリックした場 合は，登録ユーザーのみの機能である旨のメッセー ジが表示される。

c）基本情報の複数件処理対応

（図2中(3)）検索結果画面で，一覧表示されている 各基本情報にチェックボックスがついた。チェック をすることにより，まとめて詳細情報の表示やブッ クマーク登録ができる。また，文献タブを選択した 際には，まとめて文献管理ソフトにインポート可能 な書誌データがダウンロードできる。書誌データの フォーマットはJ-STAGEでも採用しているBibtex形式 とRIS形式の2種類をサポートしている。

d）名寄せID (仮称) 検索

JSTでは平成21年度，1981年から2008年までのJST 文献情報および，公開日が1993年から2008年までの 特許情報を対象に「著者名名寄せシステム」の開発 
を行った。「著者名名寄せシステム」では共著者やそ のフリガナ，共発明者，所属機関名，文献の索引情 報などを基に「同姓同名の排除」や「著者名表記ゆ れの解消」を精度高く行い，名寄せデータベースを

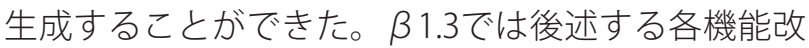
善において，この名寄せデータベースを特許や文献， 研究者情報の表示において活用した。ここでは検索 結果画面での活用例として「名寄せID（仮称）検索」 を紹介する。

（図2中(4)）文献や特許の一覧表示の際に，その「著 者名」(文献)，「発明者」(特許) エリアに新たにリ ンクが追加された。この人名リンクには18栴から成 る名寄せIDが埋め込まれており，リンクをクリック することで，名寄せIDによる検索が実行される。名 寄せID検索の結果の表示は通常の検索結果画面と同 様だが，検索語が名寄せIDを含む特殊な文字列とな る。この検索結果の絞り込みエリアでは，注目して いる著者（発明者）に関するさまざまな観点の情報 を得ることができる。

なお，今回の名寄せ処理の範囲外（1980年以前の 文献，2009年以降の文献と特許）の「著者名」や「発 明者」にはリンクがついていないのでご注意いただ きたい。今後，過去分および最新分について名寄せ 処理を行う予定である。

e) 名寄せID絞り込み

（図2中(5)）検索結果の絞り込みエリアに新たに「名 寄せ著者」(文献)，「名寄せ出願人」(特許)，「名寄 せ発明者」（特許）を追加した。これらは，検索した 集合に対して名寄せIDを集計したものである。前項 で記したように名寄せ処理範囲外の文献については 集計されないため，ご注意いただきたい。

\subsection{2 画面改善（詳細画面）}

ここからは詳細画面デザインの改善点について紹 介する (図3，4）。

a) GoogleニュースAPI

（図3中(1)）J-GLOBALは基本情報として研究者名や
機関名，科学技術用語や化学物質名などを持ってい る。これらの見出し語をキーワードとして，Google ニュースAPIにて検索し，提供する各種新聞，二ュー スサイト等の記事へのリンクを取得し，各基本情報 の詳細画面に表示している。

b）関連情報の表示位置の変更

（図3中(2)）これまでのJ-GLOBALでは詳細画面の右 のエリアに関連情報へのリンクを表示していたが， これを画面下部に配置した。これには2つのメリット がある。ひとつは利用者に気づいてもらいやすくなっ たことである。最近のWebサイトは画面の左右に広 告などの情報が表示されることが多く，利用者は無 意識に中央だけの情報を見る傾向があり，関連検索 リンクに気がつかないことがある。事実，アクセス 統計などを見ても関連検索の利用は多くない。もう ひとつは右のエリアがなくなったため，折り返しが 減り，縦スクロールの量が軽減されることも期待さ れる。前項のGoogle二ュースAPIの表示も同様に画面 下部に配置している。

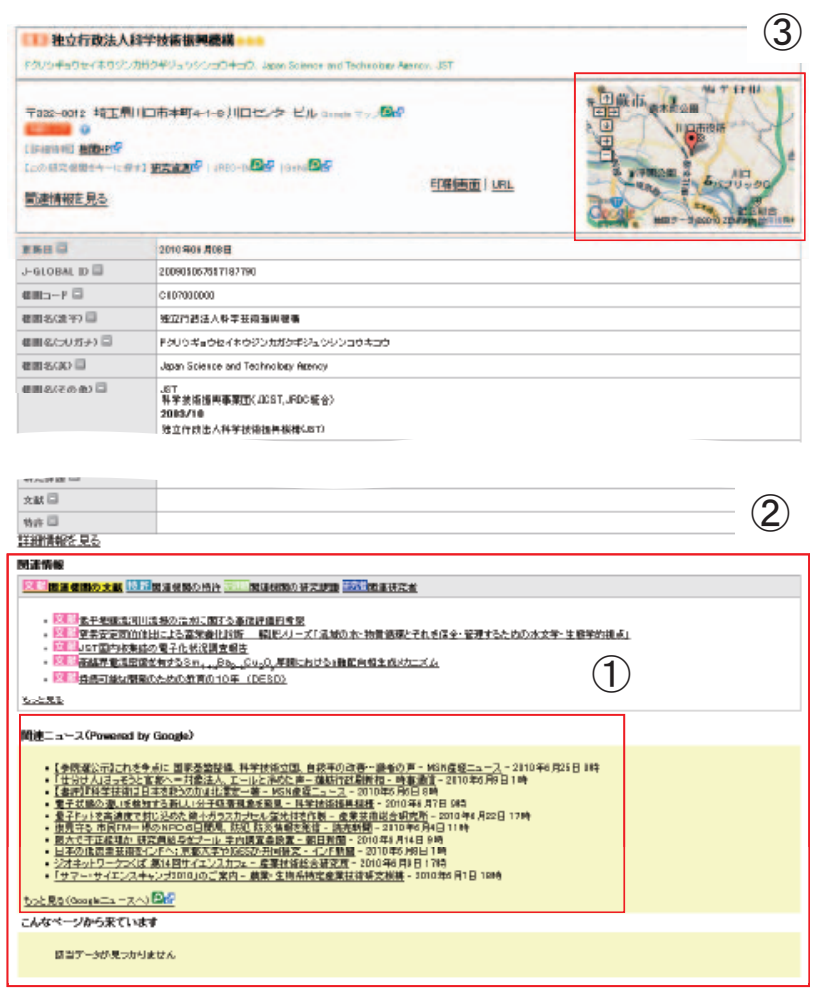

図3 詳細画面の改善点（機関の例） 
c) GoogleマップAPIによる地図画像のインライン表示

（図3中(3)）基本情報「大学・研究所」はRea $\mathrm{D}^{7)}$ の 機関情報および機関名辞書を由来としている。ReaD 由来の機関情報には所在情報が含まれており，これ までもGoogleマップへのリンクが実現されていた。 今回の改善ではGoogleマップAPIを利用し，所在情報 を画像として詳細画面内に表示することとした。

d）研究者詳細画面での推定論文・特許の名寄せ結果

\section{反映}

名寄せデータベースはJST文献データを識別する整 理番号や特許情報を識別する特許番号と，名寄せID とを紐づけて管理している。一方，ReaDの研究者情 報には研究者より研究業績情報として論文や特許の 情報を入力いただいている。JSTではこのReaDの研 究業績情報とJST文献データベースや特許データベー スとの書誌マッチングを実施し，整理番号もしくは 特許番号が得られた業績情報については，それぞれ の詳細画面へのリンクを実現している。これにより， 研究者とその業績情報としての文献や特許の情報が 紐づくため，それを基に名寄せデータベースから当 該整理番号や特許番号が含まれている名寄せIDを取 り出して，研究者詳細画面において，推定される文献・ 特許として，当該研究者の業績情報として表示して いる。この仕組みはReaDへ業績情報の入力が必要な ため，入力されていない場合は残念ながら表示する ことができない（図4）。

\subsubsection{My J-GLOBAL}

My J-GLOBALとはメールアドレスとパスワードを 登録し，アカウントを作成することで，J-GLOBAL をより便利に活用いただく機能を提供するものであ る。My J-GLOBALは大きく分けて次の機能を提供し ている。

・アラート機能

・ブックマーク閲覧

- 閲覧履歴／操作履歴閲覧

-WebAPI申請
・表示設定保存

・アカウント管理

ここでは，MyJ-GLOBALで提供している新機能お よび既存機能の变更点について紹介する（図5)。

a）アラート機能

J-GLOBALに登載している基本情報のうち，文献， 特許，研究課題を対象にデータ更新ごとに更新分デー タの中から，指定したキーワードを含む情報があれ ば，それをメールでお知らせするとともに，Webペー ジ上で該当の情報を見ることができる機能である。 アラート登録には，基本情報の種別（文献，特許， 研究課題)，アラートの内容を示すタイトル，検索キー ワードを入力する。

配信メールにはヒットしたアラートのタイトル， 件数などが含まれるが，結果のコンテンツは含まれ

\begin{tabular}{|c|c|c|}
\hline \multicolumn{3}{|c|}{ 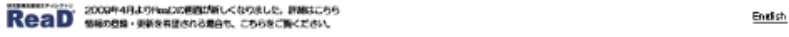 } \\
\hline \multicolumn{3}{|c|}{ 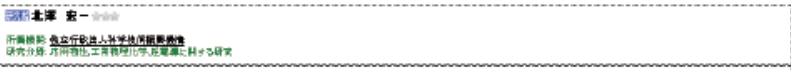 } \\
\hline \multicolumn{3}{|c|}{ 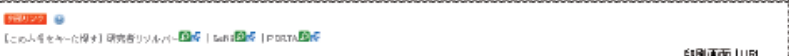 } \\
\hline exta & 20MAOSNOSB & \\
\hline 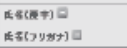 & 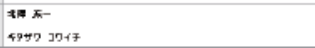 & \\
\hline K8(a- & 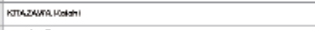 & \\
\hline $2 * n$ 日 & 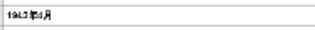 & \\
\hline 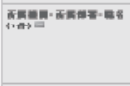 & 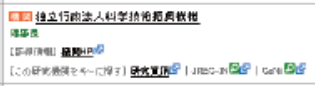 & \\
\hline
\end{tabular}

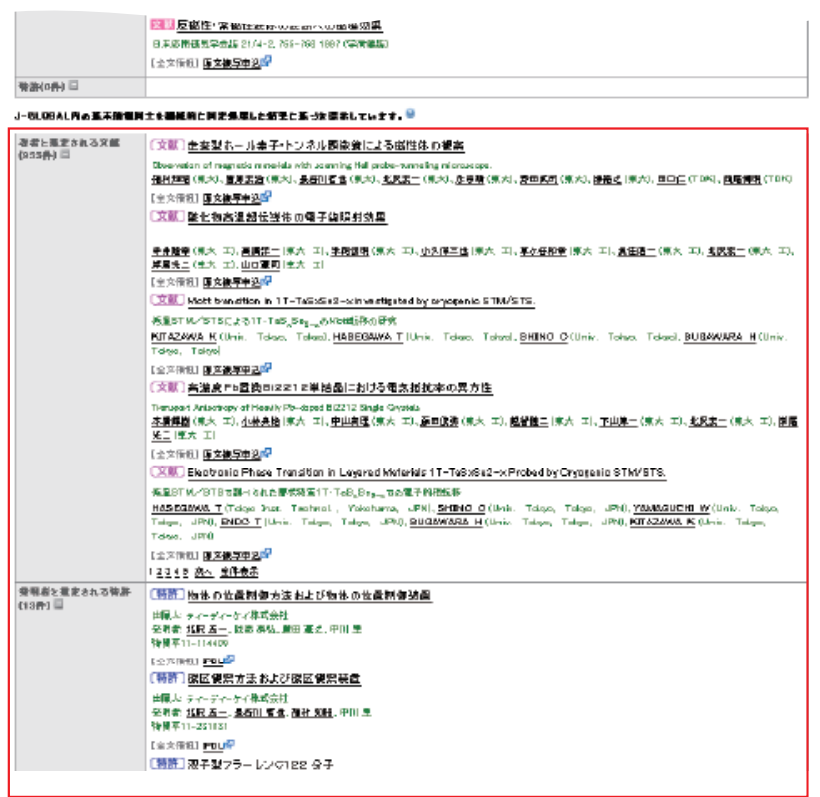

図4詳細画面の改善点（研究者の例） 


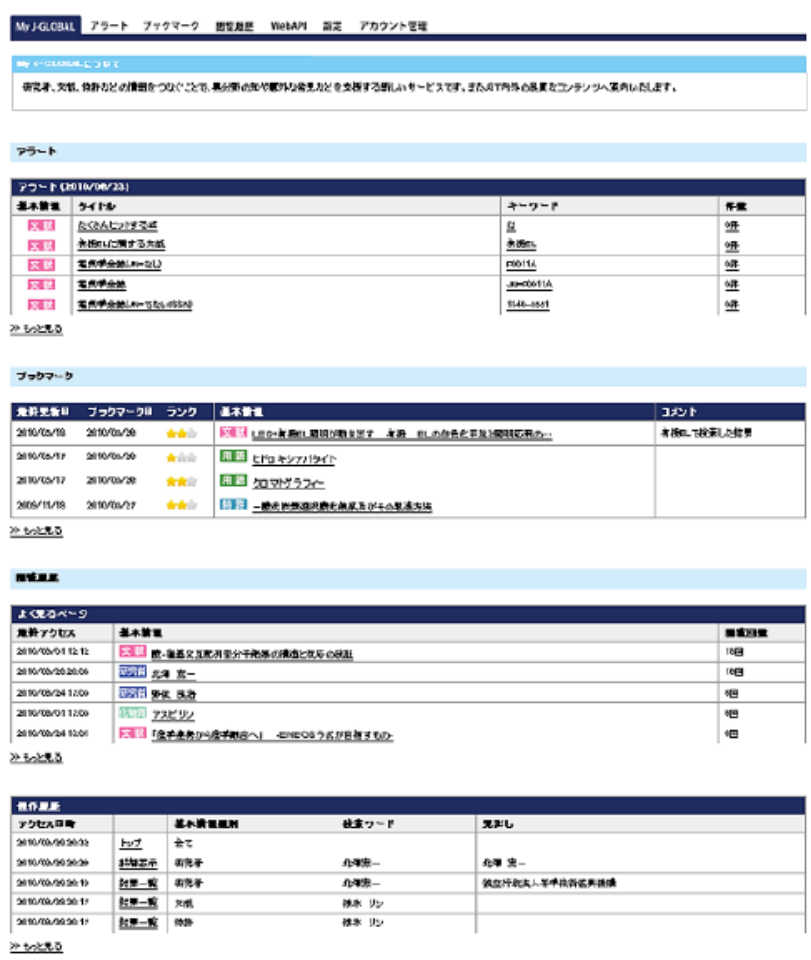

図5 My J-GLOBALトップページ

ない。

b）ブックマーク閲覧

ブックマーク閲覧は，各画面で基本情報に対して 々印をクリックして登録されたブックマークの一覧 を表示し，利用者が気になった情報に容易にたどり 着くことを支援するものである。ブックマーク閲覧 画面ではランク変更（星1つから星3つ）や削除，ブッ クマークした基本情報にコメントを付与することが できる。

\section{c）閲覧履歴／操作履歴閲覧}

これまでも検索や詳細閲覧などの履歴を保存す る仕組みを用意していたが，Cookie保存でかつブ ラウザを閉じると消えてしまっていた。今回のMy J-GLOBALのリリースにより，ログインすることで履 歴をサーバに3か月間保存することとした。また，詳 細情報の閲覧回数の多い順にトップ20を表示し，操 作履歴はカレンダーを操作することで1日単位で操作 履歴を振り返り，当時の検索を再現することができ る。

\section{d) WebAPI申請}

B1.2よりリリースされたWebAPI申請をMy J-GLOBALの中に組み込んだ。

e）表示設定保存

トップページ等に配置されているポートレット（お 知らせやホットな検索キーワードなど移動可能な小 空）の表示／非表示や，検索結果画面の表示件数設 定などをサーバに保存する。これにより，異なる端 末からの利用であっても設定した内容で表示される。

\section{f）アカウント管理}

従来の入力項目に加え，アラート配信メールの希 望の有無の項目を追加した。

g）トップページへのMy J-GLOBALポートレットの追加 My J-GLOBALの各機能のうち，アラート機能，ブッ クマーク閲覧，閲覧履歴／操作履歴については， J-GLOBALトップページのポートレットからもアクセ スできるようにした。ただし，アラート機能，ブッ クマーク閲覧については，ログイン時のみ有効であ り，未ログイン時にはログインを促すメッセージが 表示される。

\subsection{4 データ拡充／リンク拡充}

B 1.1ではデータ拡充として1993年以降の文献，特 許情報を登載し，さらにß1.3では1975年から1992年 までの文献書誌を登載した。これにより，JST文献デー タベースのうち，J-GLOBALに登載可能な情報はすべ て登載したことになる。

リンク拡充としては，農林水産省 農林水産研究 情報総合センター（AFFRIT）が運営する農林水産分 野に特化した情報サービスであるAGROPEDIA8) 内 のJASI (Japanese Agricultural Sciences Index，日 本農学文献記事索引）データベース，約70,000件が J-GLOBALの文献情報との間でリンクを実現した。

また，特許情報ではライセンス可能な特許情報等 を提供するJ-STORE ${ }^{9)}$ より，「公開特許」に加えて，「海 外特許」「技術シーズ」、「研究報告」の各ページへ のリンクを追加した。 


\subsection{5 関連検索の精度の向上}

ある基本情報に関連する他の基本情報を案内する 関連検索は，各基本情報を特徵づけるキーワードを いかに適切に抽出するかがポイントとなる。以降， 基本情報ごとに今回の改善のポイントを示す。

\section{a）研究者情報}

研究者情報における内容類似の関連検索において は，これまで研究者自身が登録した研究分野や研究 テーマを「内容類似」として関連度を求めていたが， これらの情報が入力されていない場合や入力が少な い場合は適切な関連度を求めることができなかっ

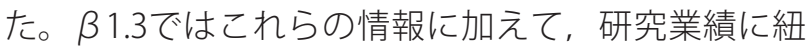
づけられた文献情報の索引情報を集計し，出現頻度 の高いキーワードを抽出して，関連度計算に用いる こととした。

\section{b）文献情報}

文献情報における内容類似の関連検索においては， これまで当該文献情報の書誌（論文タイトルの切出 し語）や事項索引を「内容類似」として関連度を求 めていたが，これをさらに強化し，事項索引の中で 特に主題索引（見出し語索引）されているものについ ては，重みづけを考慮した上で関連度を求めることと した。

\section{C）特許情報}

特許情報における内容類似の関連検索においては， 「内容類似」とする用語抽出範囲が「発明の名称」「要 約」，「請求項」と広範囲に及ぶため，特許情報中の 出現頻度の高い用語の抽出と，一般的用語（「システ ム」等）を排除するための不要語リストを用いて適 切な用語抽出をした上で関連度を求めることとした。

\section{d）不適切な結果が予想される関連検索の中止}

関連度を求めるにあたり，抽出するキーワードが 存在しない，もしくは抽出キーワードが少なく，関 連度スコアが著しく低くなる場合については関連度 の計算を中止することで，不正確な関連情報を表示 しない仕組みとした。

\section{4. 今後の方向性}

今回の改善にあたっては，3つの方針を掲げ，それ ぞれの観点で改善を行った。以下に今回の改善ポイ ントと今後の方向性を示す。

(1)網羅性の向上：文献の登載範囲をJST文献データ ベースの1975年〜最新分に拡充。特許の登載範囲 を1993年〜最新分に拡充。今後はトムソン・ロイ ターが提供するWoS (Web of Science) のうち， 所属機関にJAPANを含む文献の追加を予定してい る。また，機関データの拡充を予定している。

(2)連携の拡充: 今回の改善により，文献情報につい てはAGROPEDIAのJASIデータベース，特許情報に ついてはJ-STOREとのリンクを拡充した。今後も， 良質で魅力的なコンテンツを持つサービスとの連 携を引き続き模索していきたいと考えている。

(3)関連精度の向上: 今回の改善により，関連度計算 時のキーワードの抽出方法や重みづけを考慮した 計算方法を実装した。今後は過去分（1980年以前 の文献）や最新分（2009年以降の特許と文献）に 対しても名寄せ処理を実行していく予定である。

\section{5.おわりに}

JSTでは2009年3月に将来10年を見通した今後5年の ビジョンとして「学と産の間の科学技術ネットワー クを築き，科学技術に基づくイノベーションの創出 に貢献する」ことを揭げた。それを受けて，JSTの 情報事業では平成21年度に「イノベーション創出に 貢献する情報提供サービスとは何か」をテーマに有 識者へのヒアリングを実施した。その結果からは人 物情報への二ーズが多いこと，科学技術情報とビジ ネス情報の連携が有効であること，情報活用の二ズは業種によって異なることなどが示唆された。 J-GLOBALはReaDで収集された研究者情報を提供して おり，研究者の業績としての論文や特許の情報との 確実なリンケージも今回の名寄せシステムの構築に 
よって一歩前進した。「情報は人についてくる」「know whoが最も重要」といったコメントもあり，人物探 索サイトとしての位置づけが今後のJ-GLOBALサービ スが他のサービスとの差別化を図りつつ，利用者の 満足度を向上する鍵を握っているだろう。
一方，システムに目を向けると，各種データの登 載や利用増に伴いハードウェア資源が耐えられるか が今後の課題として挙げられる。検索方式の抜本的 な見直しも視野に入れて，利用者の期待に応えられ るサービスの提供を維持できるようにしていきたい。

\section{参考文献}

1) 科学技術振興機構. J-GLOBAL. http://jglobal.jst.go.jp/, (accessed 2010-06-28).

2）松邑勝治，黒沢努，関根基樹，矢口学，植松利晃，加藤治.「J-GLOBAL」試行版（ $\beta$ 版）の構築と今後の展望. 情報管理. 2009, vol. 52, no. 3, p. 150-157.

3）科学技術振興機構. J-GLOBAL利用者アンケート結果. http://jglobal.jst.go.jp/info/report/trend_reportH21. pdf, (accessed 2010-07-09).

4) 植松利晃, 松邑勝治, 黒沢努, 加藤治. “J-GLOBAL（科学技術総合リンクセンター）のサービス向上への取組 み：ヒアリングに見るサービス拡充の方向性”. 第6回情報プロフェッショナルシンポジウム予稿集. 東京, 2009-10-14/15, 科学技術振興機構, 情報科学技術協会共催. 2009, p. 55-60.

5）科学技術振興機構. “お知らせ (Ver 1.2) WebAPI提供についで. J-GLOBAL. http://jglobal.jst.go.jp/footer. php?page=webapi, (accessed 2010-06-28).

6）日経BP社. 日経BPビズボード. http://bizboard.nikkeibp.co.jp/, (accessed 2010-06-28).

7) 科学技術振興機構. ReaD. http://read.jst.go.jp/, (accessed 2010-06-28).

8）農林水産省. “AGROPEDIA”. 農林水産研究情報総合案内. http://www.affrc.go.jp/Agropedia/, (accessed 2010-06-28).

9) 科学技術振興機構. J-STORE. http://jstore.jst.go.jp/, (accessed 2010-06-28).

\section{Author Abstract}

J-GLOBAL, provided by Japan Science and Technology Agency (JST), is a service to support finding new ideas and collecting multidisciplinary information in the stages of seeking new challenges and academia-industry cooperation. JST aims at contributing to bringing innovation in Japan by disseminating high-quality scientific and technological information through J-GLOBAL making the most of various S\&T-related databases from JST and other organizations. This article summarizes the new feature and future directions of J-GLOBAL.

\section{Key words}

J-GLOBAL, database, innovation, linkage, link center, dictionary, literature, patent, researcher, institute 